\title{
Do Epiphytes in Drier Climates Select Host Tree Substrates between Rough and Smooth Bole Textures and Crown and Stem, Vertical and Upright Stems? What Are the Implications for Water Catchment and Forest Management?
}

\author{
Chansa Chomba \\ School of Agriculture and Natural Resources, Disaster Management Training Centre, Mulungushi University, \\ Kabwe, Zambia \\ Email: chansachomba@rocketmail.com, cchomba@ac.mu.zm, ritachansa@yahoo.com
}

Received 25 May 2014; revised 25 June 2014; accepted 2 July 2014

Copyright (C) 2014 by author and Scientific Research Publishing Inc. This work is licensed under the Creative Commons Attribution International License (CC BY). http://creativecommons.org/licenses/by/4.0/ c) (7) Open Access

\begin{abstract}
Epiphyte biomass (dry weight kg) placement between rough and smooth bole bark textures; crown and trunk as well as upright and horizontal substrates in Lusenga National Park were examined through ground surveys. Transects were located at random in woody vegetation using quadrats $20 \mathrm{~m} \times 20 \mathrm{~m}$ which were located every $100 \mathrm{~m}$ along $1 \mathrm{~km}$ long transects. For every host tree substrate sampled, tree species was identified and bark texture was determined. Presence and location of epiphytes were determined through direct observation. Epiphytes were collected, dried and weighed, so as to apportion biomass between rough and smooth bole textures, crown and trunk as well as stem inclination. Rough bole textured stems had more epiphytes of $1967 \mathrm{~kg}$ $(89 \%)$ than smooth bole substrates of $313.48 \mathrm{~kg}(11 \%)$ and also inclined stems had higher biomass of $85 \%$ than vertical stems of $14.64 \%\left(\chi^{2}=P<0.005\right)$. Trunk had less biomass of $32 \%$ and crown had higher biomass of $68 \%$ (Mann Whitney $U$ test $0.002<P<0.05$ ). It was concluded that epiphytes were more abundant on rough bole textured substrates and in crown than stem. It would appear that rough bole textured substrates provided better physical anchorage and stability against dislodging forces of wind and rain water, hence being suitable for epiphyte establishment and survival. Inclined substrates on the other hand provided a suitable habitat for accumulation of debris and moisture retention, seed settling, germination, and maximum exposure to sunlight all of which support germination and growth of epiphytes. Further research is required to determine
\end{abstract}


successional colonization, incidences of host species specificity, rain water interception and retention and impact of fire on epiphyte biomass as these are important water catchment attributes.

\author{
Keywords
}

\author{
Epiphyte, Humid, Bark Texture, Rough Bole, Smooth Bole, Horizontal
}

\title{
1. Introduction
}

Epiphytes require the support of physical structures for anchorage [1]. On trees, they occur on any part: trunk, branches and sometimes on the upper leaf surface (e.g. lichens), though Eleanor [2] recorded a higher preference for horizontal branches on which considerable depth of humus often collects. Kelly [3] and Cornellissen [4] argued against selection of certain positions and found that they rather depended on succession stage of the vegetation community implying that older forest communities held more epiphytes than secondary or lower seral stages. Yeaton and Gladstone [5] and Catling and others [6] supported the earlier assertion by Catling and Lefkovitch [7] that younger host trees which are characteristic of secondary forests supported fewer and different epiphytic associations usually non-vascular, from those supported by older substrates in older forest communities [1]. This was because vascular epiphytes required a deeper mantle of organic matter and a larger surface for anchorage [1] [8] and required a more humid environment characteristic of primary forests [1].

All the above studies except for Chomba and others [1] were conducted in high rainfall tropical areas with high humidity approaching $100 \%$. Therefore, this study further strengthens the earlier study by Chomba and others [1] which is now the second in roll to focus on epiphytes in Miombo woodland in Zambia, a vegetation community typical of the Zambezian Regional Centre of Endemism, which is poorer in tree species diversity, cover and humidity. It is here, in drier climates where the distribution of epiphytes is ecologically critical as it indicates rainfall regimes and their decline or disappearance would be an important ecological indicator of environmental disturbance or declining rainfall regime. In addition to being indicators of high rainfall and humidity levels, they also indicate primary/mature forest in which they play an important role of intercepting raindrops and aerosols such that in areas of increasing air pollution, they are the best aerial community from which the level of air pollution can be determined [1]. This study therefore, was carried out to further reinforce the earlier study [1] which did not cover in detail the influence of rough and smooth bole textures and stem inclination as important attributes characterizing distribution of epiphytes biomass in wet Miombo woodlands.

It was thought that results arising from this study would further reinforce earlier findings [1] and be used by Department of Forestry (FD), Zambia Wildlife Authority (ZAWA) and National Heritage Conservation Commission (NHCC), Zambia Environmental Monitoring Agency (ZEMA) and Local Communities to safeguard these important primary forests from excessive extractive uses, late fires and to guard against increasing pressure to have them developed for outdoor recreation, which may in the long term lead to loss of primary ecological services they provide. Specifically the research sought to determine the following: 1) epiphyte biomass pattern of distribution between rough and smooth bole substrates; 2) effect of trunk inclination on abundance and distribution of epiphytes; and 3) distribution between crown and stem.

\section{Methods and Materials}

\subsection{Study Area}

\subsubsection{Location and Description}

The Lusenga Plains National Park is located in Kawambwa District of Luapula Province. It is $880 \mathrm{~km}^{2}$ in extent and geographic location is longitudes $28^{\circ} 55^{\prime}$ East and $29^{\circ} 12^{\prime}$ South latitudes (Figure 1).

\subsubsection{Climate}

The Lusenga Plains National Park is located in one of the four high rainfall cells of Zambia receiving $\geq 1000 \mathrm{~mm}$ rainfall per annum and experiences; cool and dry season from April to August, hot and dry from September to October and hot and rainy from November to March/April. Mean annual temperature is $18^{\circ} \mathrm{C}-22^{\circ} \mathrm{C}$ and 


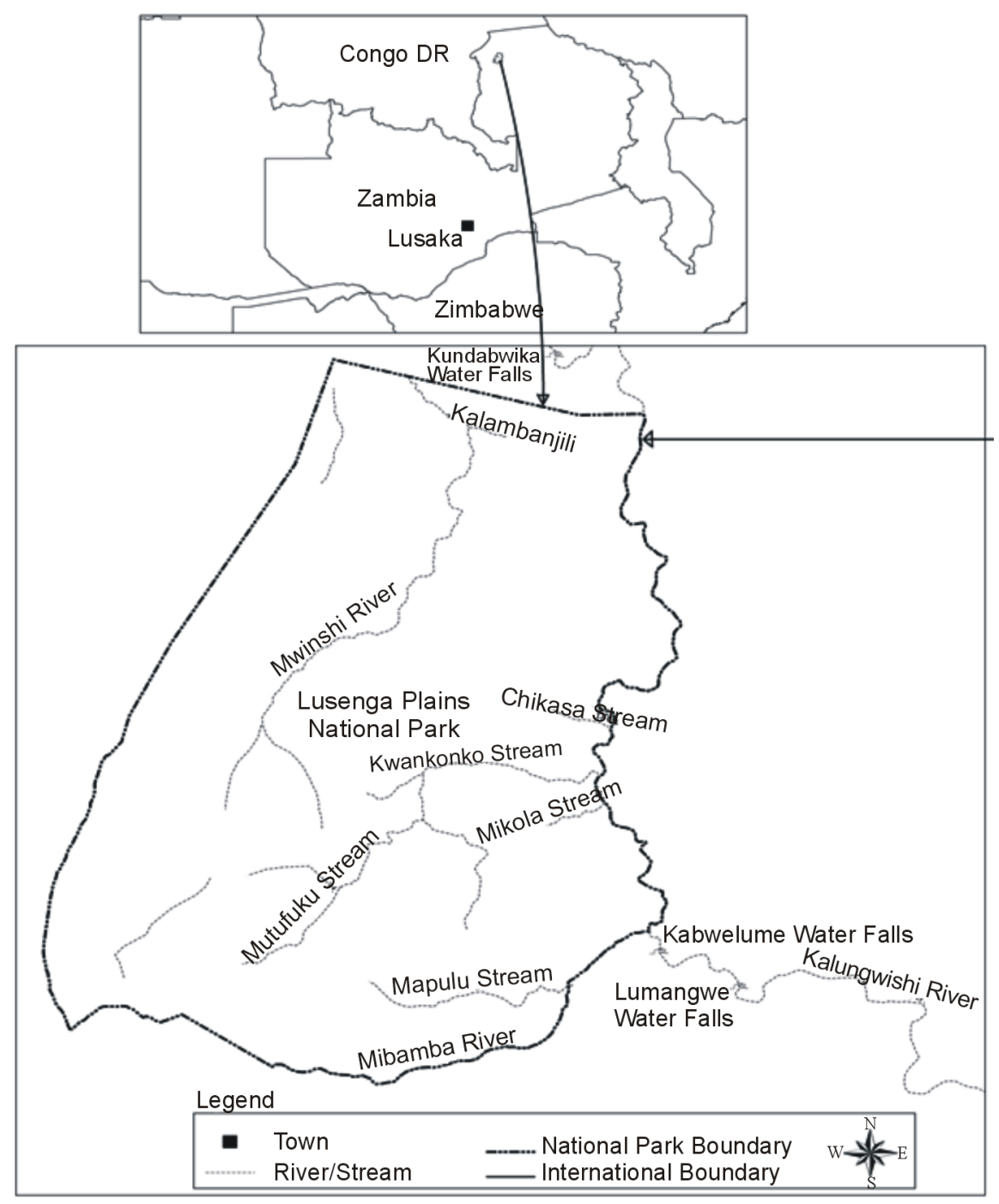

Figure 1. Location of study area, Lusenga Plains National Park and adjacent surroundings, Zambia (source: Zambia Wildlife Authority, GIS Laboratory).

monthly mean for June and July, which are the coolest months, is $15^{\circ} \mathrm{C}-17^{\circ} \mathrm{C}$ and $23^{\circ} \mathrm{C}-28^{\circ} \mathrm{C}$ for September and October which is also the hottest month of the year.

\subsection{Field Methods}

This study is part of the long-term monitoring programme established in the area before 2004. The study was carried out in Lusenga Plains National Park and adjoining waterfalls at Lumangwe, Kabwelume and Kundabwika waterfalls as part of the ongoing long-term study usually conducted every September 2004-2012/13. Woody vegetation types were sampled for epiphyte location/position on the host tree as earlier described and carried out [1].

\subsubsection{Biomass Distribution between Rough and Smooth Substrates}

Epiphyte distribution between rough and smooth bole textures and stem inclination (Figure 2(a), Figure 2(b), Figure 2(c)) were collected while sampling along transects $1 \mathrm{~km}$ long which were located at random and laid parallel to each other to prevent crisscrossing. There was no clearing along transects as cutting of trees would be in direct conflict with the objectives of the study. Instead the researcher walked ahead of the team along an imaginary line with aid of a pair of campus (Figure 3). 


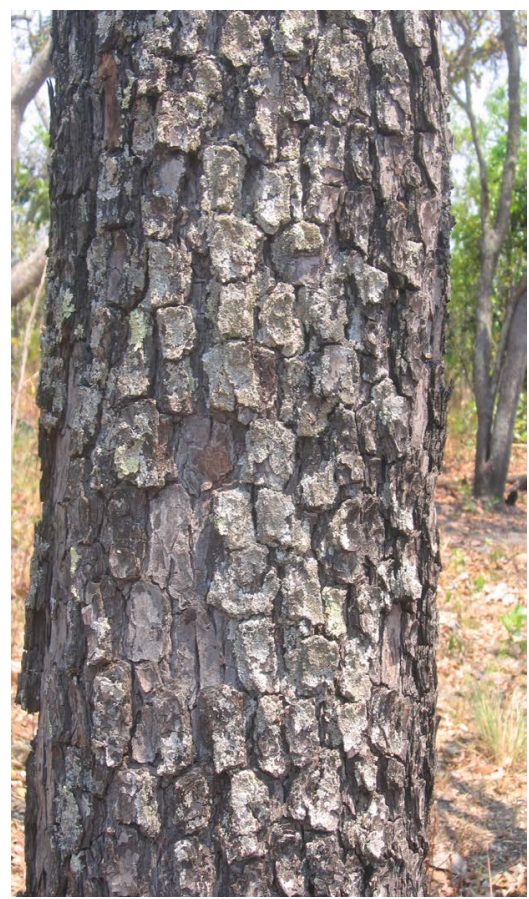

(a)

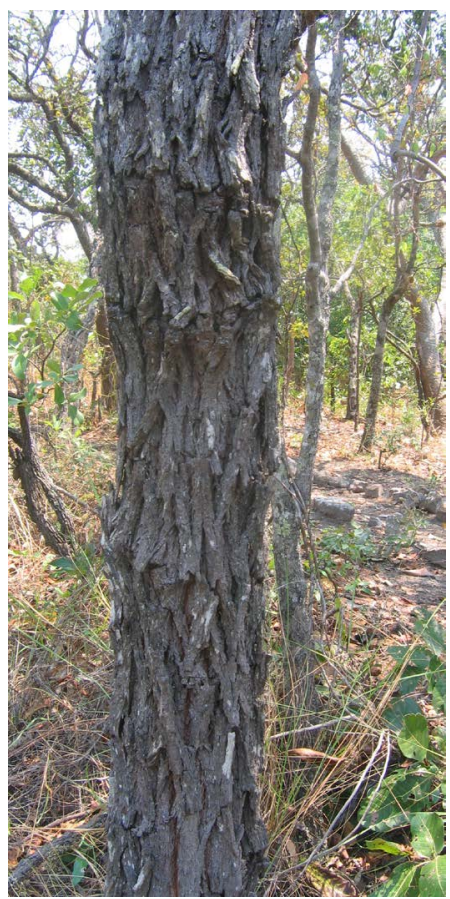

(b)

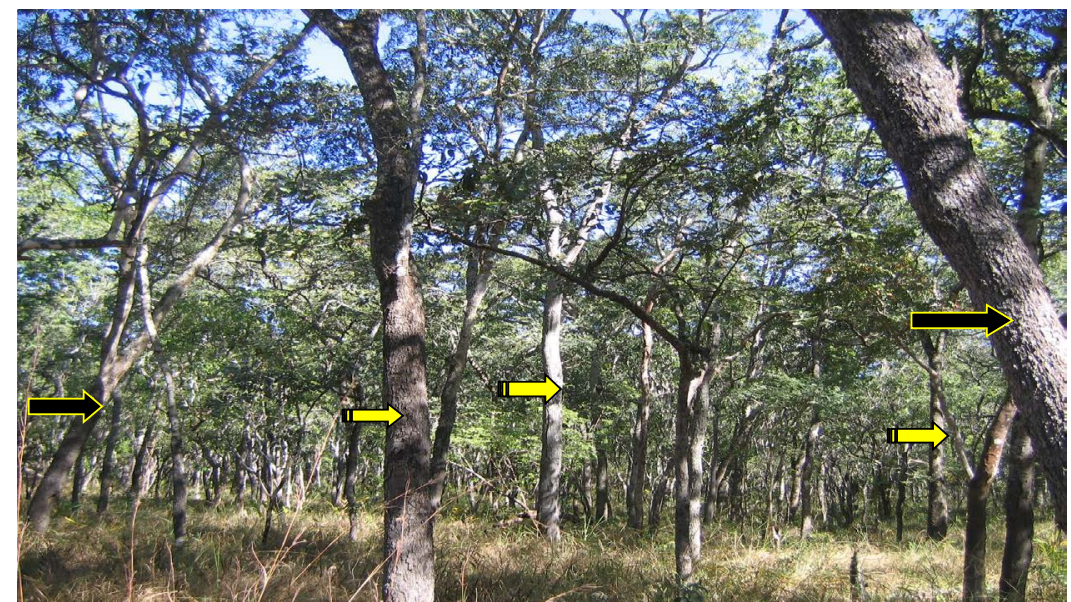

(c)

Figure 2. (a) Rough bole substrate of Pterocarpus angolensis with reticulately ridged scales like crocodile skin; (b) Longitudinal vertical fissures with raised oblong flakes of Terminalia spp.; and (c) Horizontal/inclined and upright trunks, yellow arrows represent upright stems and black arrows inclined trunks, Lusenga Plains National Park, Zambia.

Transect lines were separated by a minimum distance of 50 metres inside the National Park and $10 \mathrm{~m}$ near the waterfalls as in earlier study. Along each transect, quadrats $20 \mathrm{~m} \times 20 \mathrm{~m}$ in size were stratified every $100 \mathrm{~m}$ and sampling was done based on the earlier approach [1] as modified after Gentry and Dobson [9]. Epiphytes found within the quadrat and their presence were allotted to rough or rough bole texture classes and stem inclination of upright and inclined (Figure 2(c)). Lichens, Usnea articulata and Ramalina reticulata which usually hanged on leaves to take advantage of rising mist from the water falls were left out as these due to their relative light weight, do not necessarily require big branches or stem for anchorage (Figure 4(a), Figure 4(b), Figure 4(c)).

The roughness or smoothness of the substrate was visually carried out to isolate these classes and further verified by running the inner side of the palm over the surface of the tree trunk. Rough bole texture had a prick scaly 


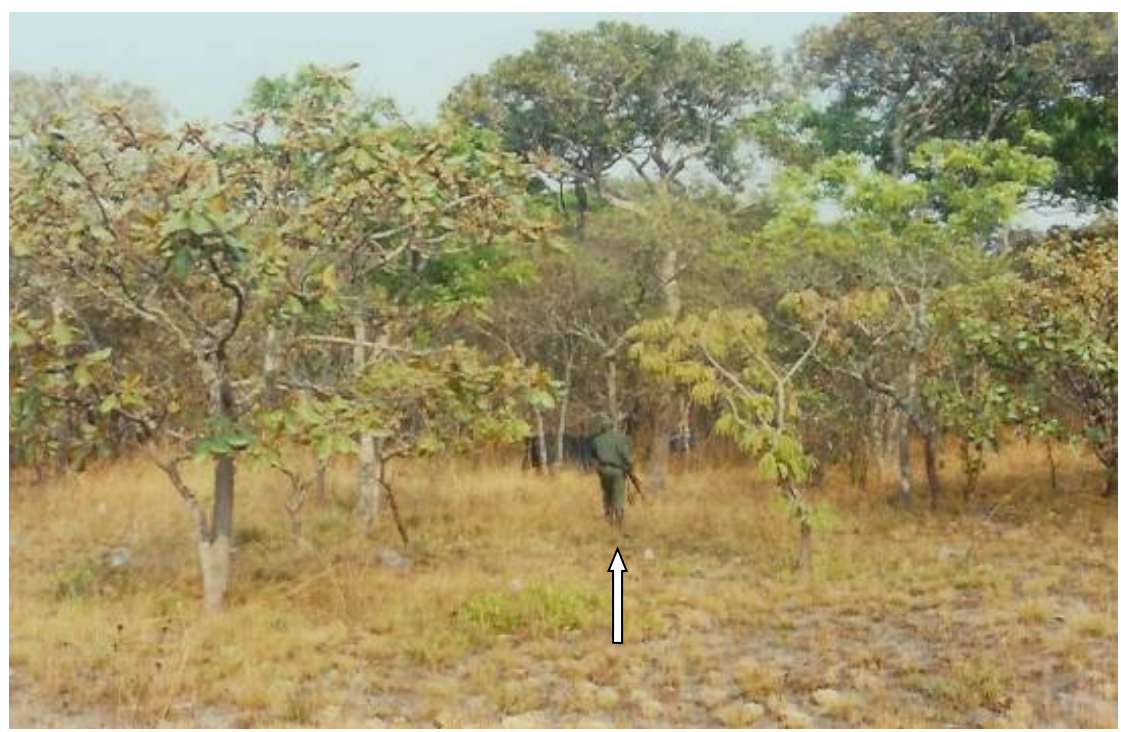

Figure 3. Research team member armed with a rifle for protection in case of dangerous game takes compass bearing to mark transect, Lusenga Plains National Park.

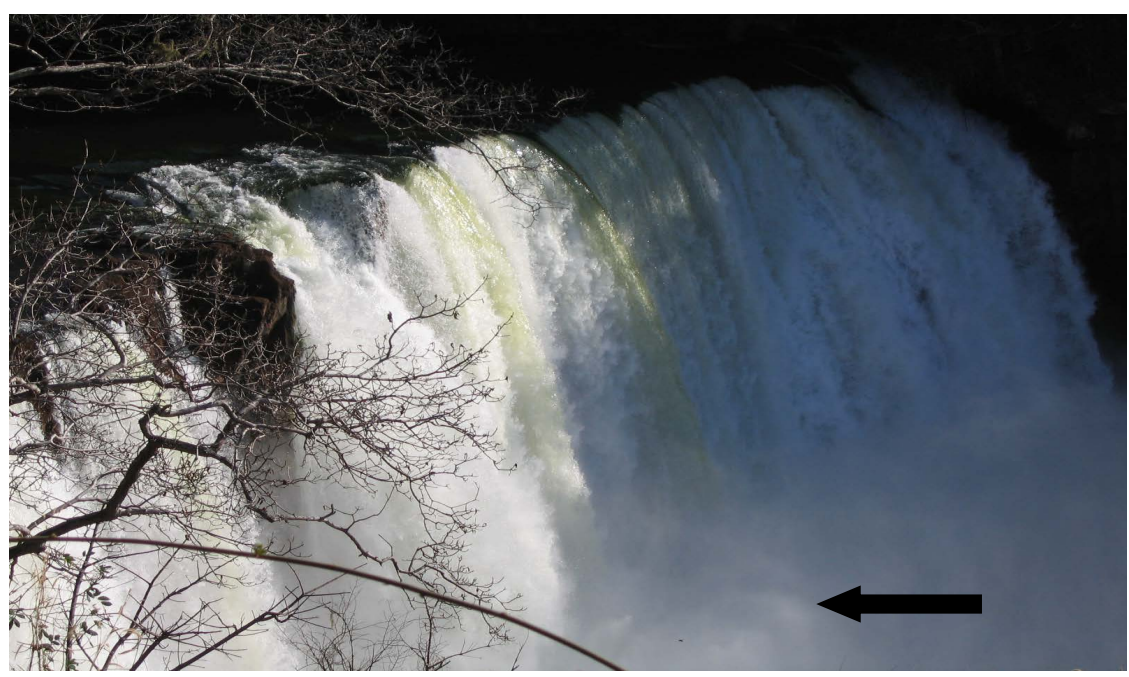

(a)

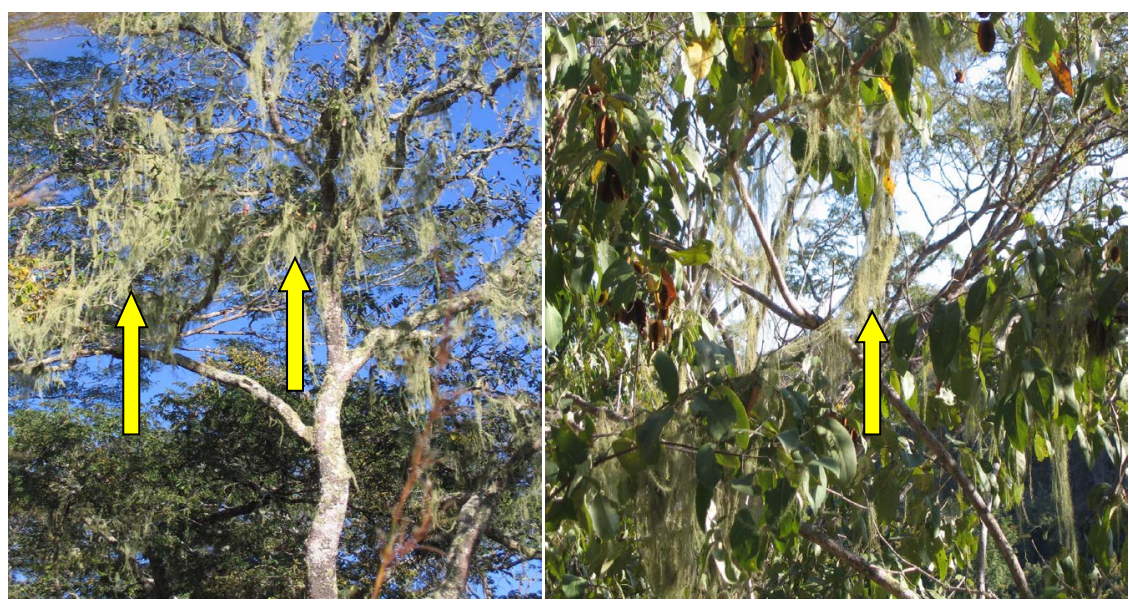

(b) 


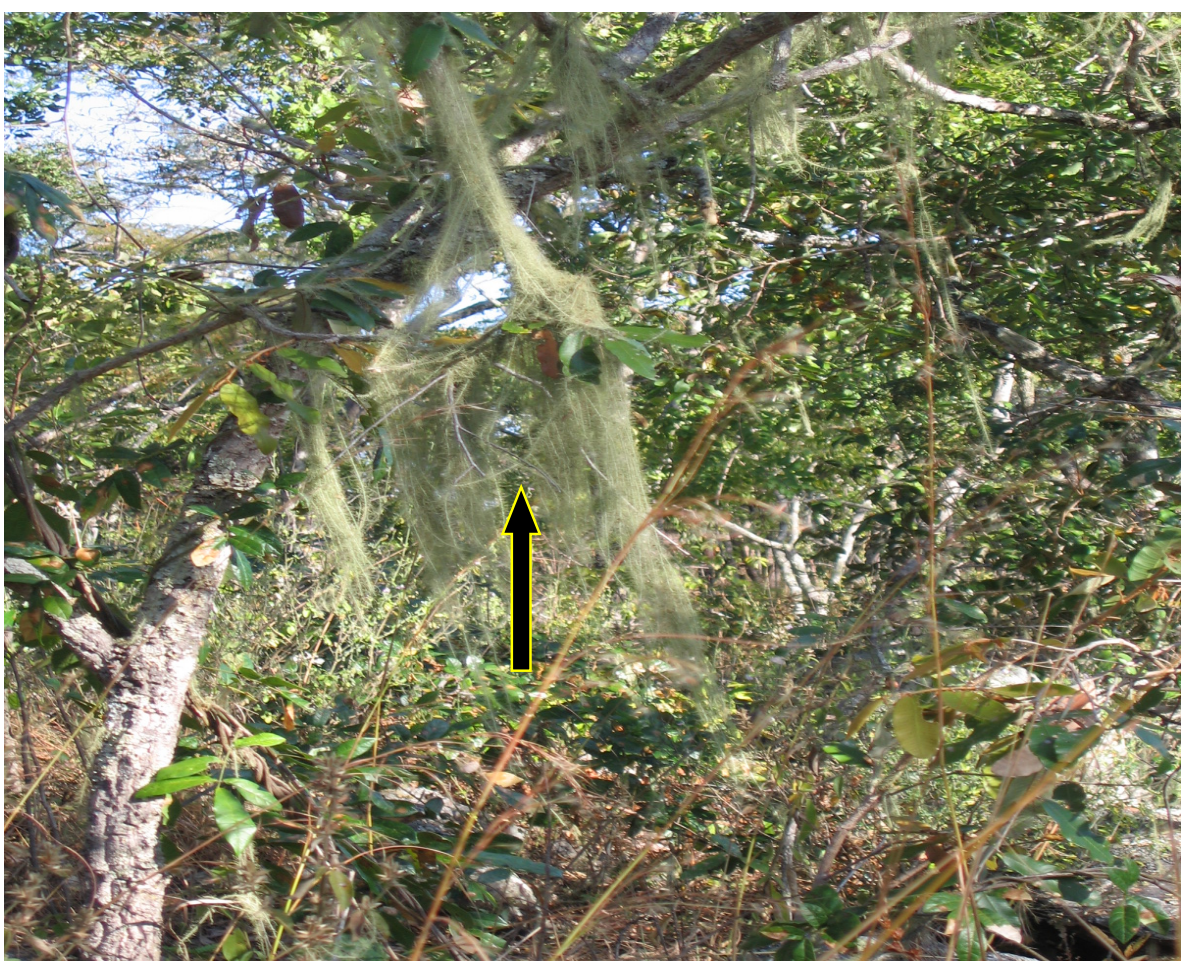

(c)

Figure 4. (a) Kundabwika Falls with mist rising which increases humidity and encourages growth of old man's beard Usnea articulata and Ramalina reticulate; (b) and (c) Ramalina reticulata and Usnea articulata on tree crown taking advantage of the rising mist from falling water, Kalungwishi River.

feel (Figure 2(a), Figure 2(b)) on the palm and sometimes caused minor bruises or lacerations on the palm while the smooth bole did not. There were only two categories of rough and smooth bole textures developed and each substrate examined was subjectively allocated to either rough or smooth categories only. Stem inclinations was done visually as upright when the stem is near $180^{\circ}$ and inclined when less than $180^{\circ}$ including those lying on the ground. Stem inclination classification was practical as the researcher had earlier carried out a similar study on Mount Meru in Tanzania in 1993 and initiated the Lusenga Plains National Park epiphyte monitoring strategy. Epiphytes sampled along transects were recorded under the respective stem inclination and categories of rough and smooth bole textures.

\subsubsection{Biomass}

Tree canopies were accessed by climbing as earlier reported by Chomba and others [1] as modified after Nadkarni [10] and Tucker and Powell [11]. Epiphytes were removed from the host substrate using kitchen knife into carton boxes of various dimensions to determine volume. Wet weights were taken in the field by weighing each species with a solar weighing scale calibrated to the nearest gramme as in earlier study [1]. To get dry weight, epiphyte specimens were taken to base camp and dried to constant weight and reweighed to obtain dry weight, which was required in order to calculate biomass.

\section{Results}

\subsection{Rough and Smooth Bole Textures of Substrates}

Of all the tree species sampled, trees with rough boles texture had significantly higher biomass (dry weight) $1967 \mathrm{~kg}$ (89\%) and smooth bole textured barks had the least $313.48 \mathrm{~kg}(11 \%)$ (Mann Whitney U test, $\mathrm{P}<0.001$ ) (Table 1, Figure 5), implying that rough barks provided better physical anchorage and therefore firmer support for epiphytes. 
Table 1. Epiphyte host tree species selection and biomass between host species and vegetation communities.

\begin{tabular}{|c|c|c|c|c|c|c|c|}
\hline Code & Species name & $\begin{array}{l}\text { Bole texture } \\
\text { class }\end{array}$ & $\begin{array}{l}\text { Epiphyte position } \\
\text { on tree }\end{array}$ & $\begin{array}{l}\text { Total epiphyte } \\
\text { volume }\left(\mathrm{cm}^{3}\right)\end{array}$ & $\begin{array}{l}\text { Epiphyte dry } \\
\text { weight }(\mathrm{kg})\end{array}$ & Epiphyte recorded & \\
\hline 1 & Ficus spp. & Smooth & Crown \& trunk & 206.00 & 119.50 & Moss \& lichens & \\
\hline 2 & Diospyros spp. & Rough & Crown and trunk & 806.00 & 97.50 & Moss \& lichens & \\
\hline 3 & Syzygium spp. & Smooth & Crown and trunk & 665.60 & 152.80 & Moss \& lichens & \\
\hline 4 & Khaya anthotheca & Rough & Crown and trunk & 475.00 & 51.60 & Moss \& lichens & \\
\hline 5 & Xylopia aethiopica & Rough & Crown and trunk & 715.70 & 67.30 & Moss \& lichens & \\
\hline 6 & Vitex doniana & Rough & $\begin{array}{c}\text { Branch, axil and } \\
\text { trunk }\end{array}$ & 875.00 & 305.40 & $\begin{array}{l}\text { Moss, orchids, \& hemi } \\
\text { epiphyte (Ficus spp.) }\end{array}$ & \\
\hline 7 & Isoberlinia angolensis & Rough & $\begin{array}{c}\text { Branch, axil and } \\
\text { trunk }\end{array}$ & 417.00 & 283.00 & $\begin{array}{l}\text { Moss, orchid, \& hemi } \\
\text { epiphyte }\end{array}$ & \\
\hline 8 & Brachystegia spiciformis & Rough & $\begin{array}{c}\text { Branch, axil and } \\
\text { trunk }\end{array}$ & 317.00 & 236.00 & $\begin{array}{l}\text { Moss, orchid, \& hemi } \\
\text { epiphyte }\end{array}$ & \\
\hline 9 & Isoberlinia tomentosa & Rough & $\begin{array}{c}\text { Branch, axil and } \\
\text { trunk }\end{array}$ & 238.00 & 125.90 & $\begin{array}{l}\text { Moss, orchid, \& hemi } \\
\text { epiphyte }\end{array}$ & \\
\hline 10 & Parinari curatelifolia & Rough & $\begin{array}{c}\text { Branch, axil and } \\
\text { trunk }\end{array}$ & 714.00 & 227.70 & $\begin{array}{l}\text { Moss, orchid, \& hemi } \\
\text { epiphyte }\end{array}$ & \\
\hline 11 & Brachystegia floribunda & Rough & $\begin{array}{c}\text { Branch, axil and } \\
\text { trunk }\end{array}$ & 413.00 & 189.80 & $\begin{array}{l}\text { Moss, orchid, \& hemi } \\
\text { epiphyte }\end{array}$ & \\
\hline 12 & Brachystegia utilis & Rough & $\begin{array}{c}\text { Branch, axil and } \\
\text { trunk }\end{array}$ & 517,00 & 91.20 & $\begin{array}{l}\text { Moss, orchid, \& hemi } \\
\text { epiphyte }\end{array}$ & \\
\hline 13 & Burkea africana & Rough & Axil & 15.00 & 3.90 & $\begin{array}{l}\text { Moss, orchid, \& hemi } \\
\text { epiphyte }\end{array}$ & \\
\hline 14 & Pterocarpus angolensis & Rough & Axil & 9.00 & 5.00 & $\begin{array}{l}\text { Moss, orchid, \& hemi } \\
\text { epiphyte }\end{array}$ & \\
\hline 15 & Uapaca sp. & Rough & Axil & 21.00 & 39.50 & & \\
\hline 16 & Anisophyllea boehmii & Rough & & 7.00 & 1.50 & Moss \& orchid & \\
\hline 17 & Uapaca kirkiana & Rough & Axil & 47.00 & 5.50 & Moss & \\
\hline 18 & Afzelia quanzensis & Rough & Axil & 315.00 & 120.70 & Moss \& orchid & \\
\hline 19 & Lannea discolor & Smooth & $\begin{array}{c}\text { Branch, axil and } \\
\text { trunk }\end{array}$ & 17.00 & 41.18 & $\begin{array}{l}\text { Moss, orchid \& hemi } \\
\text { epiphyte }\end{array}$ & \\
\hline 20 & Pericopsis angolensis & Rough & Axil & 11.00 & 2.00 & Moss \& orchid & \\
\hline 21 & Marquesia macroura & Rough & Axil & 129.00 & 113.50 & Orchid & \\
\hline 22 & Hymenocardia acida & Rough & Axil & & & Moss \& orchid & \\
\hline 23 & Bauhunia peternesiana & Rough & & & & Absent & \\
\hline 24 & Berchemia discolour & Rough & & & & Absent & \\
\hline 25 & $\begin{array}{l}\text { Diplorhynchus } \\
\text { condylocarpon }\end{array}$ & Rough & & & & Absent & \\
\hline 26 & Cassia abbreviata & Rough & & & & Absent & \\
\hline 27 & Terminalia spp. & Rough & & & & Absent & \\
\hline 28 & Combretum spp. & Rough & & & & Absent & \\
\hline 29 & Ximenia spp. & Rough & & & & Absent & \\
\hline 30 & Erithrina abyssinica & Rough & & & & Absent & \\
\hline 31 & Strychnos spinosa & Rough & & & & Absent & \\
\hline 32 & Dalbergia spp. & Rough & & & & Absent & \\
\hline 33 & Lannea stulmannii & Smooth & & & & Absent & \\
\hline 34 & $\begin{array}{c}\text { Bobgunia } \\
\text { madagascariensis }\end{array}$ & Rough & & & & Absent & \\
\hline 35 & Strychnos cocculoides & Rough & & & & & \\
\hline 36 & $\begin{array}{l}\text { Pseudolachnostylis } \\
\text { maprouneifolia }\end{array}$ & Rough & & & & Absent & \\
\hline 37 & Diospyros mespiliformis & Rough & & & & Absent & Absent \\
\hline Total & & & & 6331.30 & 2119.90 & Absent & Absent \\
\hline
\end{tabular}




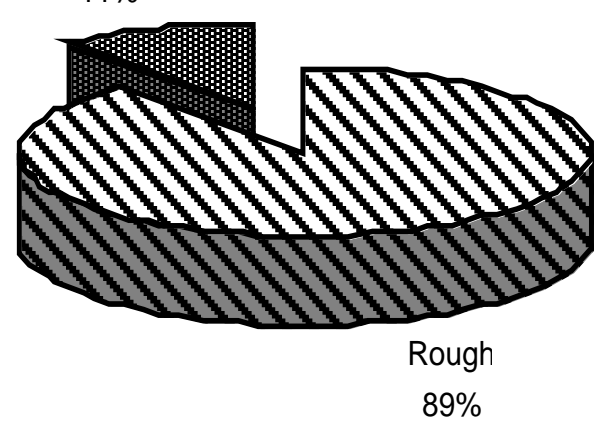

Figure 5. Epiphyte biomass pattern of distribution between rough bole and smooth bole texture of substrate, Lusenga National Park, Zambia.

\subsection{Epiphyte Abundance between Crown and Trunk}

A total of $1805 \mathrm{~kg}$ epiphyte biomass was recorded. This biomass was partitioned between different host tree locations (Figure 6(a), Figure 6(b)). The distribution between host tree locations was significantly different being higher in crown and lower in trunk (Mann Whitney U Test, P < 0.05). Crown had $1220 \mathrm{~kg}$ (68\%) and trunk 585 $\mathrm{kg}(22 \%)$ (Figure 6).

\subsection{Epiphyte Distribution between Horizontal and Inclined Trunks}

An evaluation of vertical and horizontal trunk/stem also showed that inclined trunks had significantly higher biomass $497 \mathrm{~kg}(85 \%)\left(\chi^{2}\right.$; P < 0.005) while upright stems/trunks had the least $88 \mathrm{~kg}(15 \%)$ and all the $88 \mathrm{~kg}$ were on rough bole textured trunks (Figure 7(a), Figure 7(b); Table 1).

\section{Discussion}

\section{Epiphyte Biomass Distribution}

Miombo woodland vegetation community is usually epiphyte deficient. They only occur in areas with rainfall $\geq 1000 \mathrm{~mm} / \mathrm{yr}^{-1}$. This is because epiphytes are known to be very sensitive to humidity levels and are mostly found only in habitats where humidity is usually $\geq 80 \%$ [1]. This explains why they are concentrated around the three waterfalls, Lumangwe, Kabwelume and Kundabwika and in primary forest inside the National Park. At the water falls, they take advantage of the mist plume rising after the water plunges into the gorge below and these were mainly lichens. This humid condition maintains lower plants, in this case lichens and mosses.

In areas inside the National Park and away from the water falls, moisture and humidity are lower and this explains why epiphytes were more selective of host substrates. They only selected substrates that had capacity to enhance moisture retention. Crowns for instance had more dead organic matter which undoubtly was important to the survival of epiphytes as its water retention capacity provided a more continuous moisture supply for epiphytes than the atmosphere of bare or smooth bole [12] [13]. Inclined trunks on the other hand accumulated and retained humus and moisture than vertical branches. On upright stems litter would be easily washed away by rain water or blown off by wind currents, while the inclined stems and crowns had a further advantage of nitrates from the atmosphere [10], mineralized dead organic matter accumulating on tree forks or invaginations on the stem and on inclined stems. This was in turn an important source of nitrogen for epiphytes and is probably a more reliable source than from the atmosphere [14]. It is for this reason that crowns and inclined stems which had branches, axils and invaginations in the host tree had the highest epiphyte biomass and supported epiphyte establishment (Figure 8). Although such trees may be considered to be of less timber value, their role in water retention and catchment functions is unsurpassed.

A vertical stem/trunk retains almost no wet season rainfall and experiences more rapid run off than an inclined or sloping trunk. On vertical trunks the influence of gravity is higher and less on sloping stems and this would directly or indirectly influence seedling settling and propagules. 


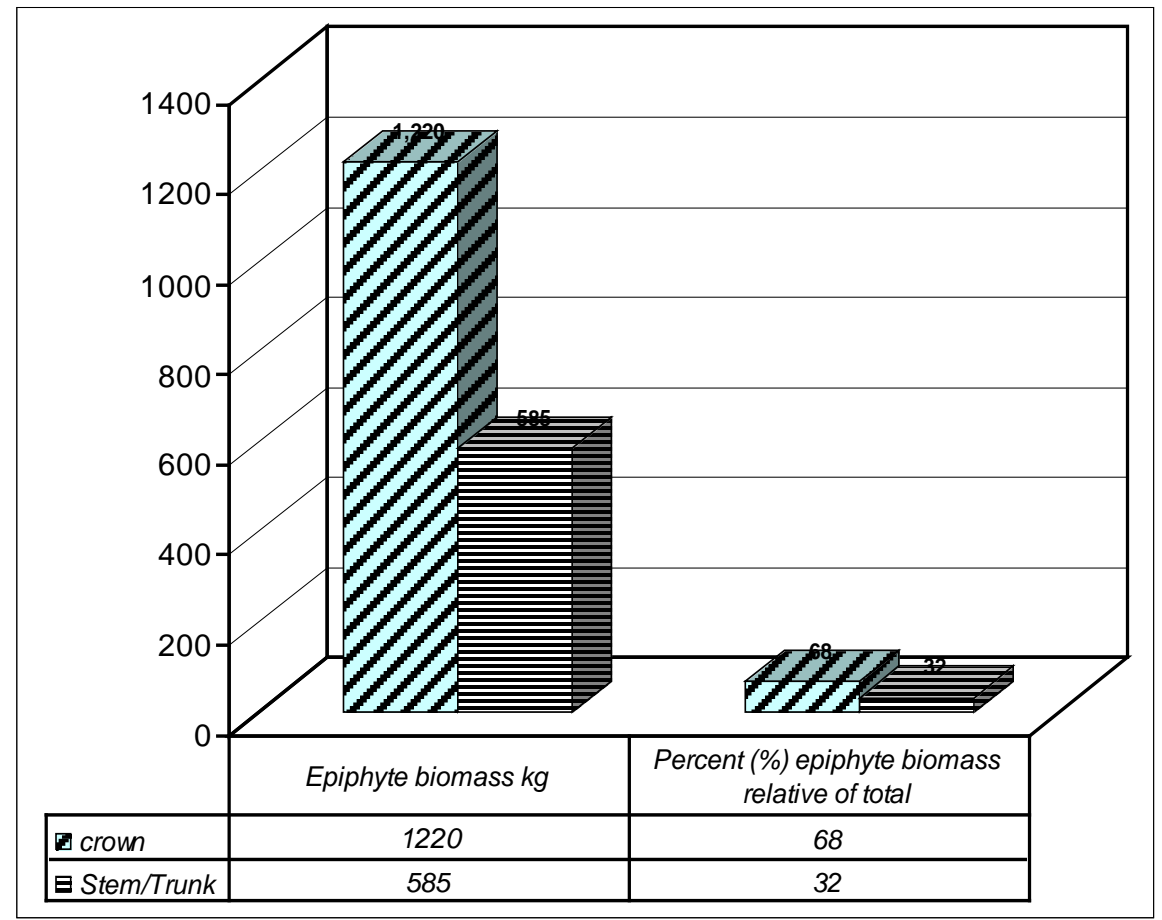

Figure 6. Epiphyte biomass pattern of distribution between crown (horizontal and trunk, Lusenga Plains National Park, Zambia).

On rough bole textured trunks, sometimes the bark peels off and if the trunk is inclined they may not fall off but settle and this combined with accumulation of moisture accelerates bark decay which provides exudates utilized by epiphytes. Barkman [15] noted that such conditions improved physical anchorage of seeds, spores, and propagules. Likewise, interception of light and water increased as the trunk becomes less and less vertical. Increasing sloppiness as already mentioned, promotes settling of seeds and spores and the accumulation of organic matter. Such conditions provided a suitable medium for epiphyte establishment [1] [15] and are critical water catchment attributes. These properties favoured horizontal trunks and rough bole textured substrates to have more epiphytes than smooth and vertical substrates.

A further explanation on the abundance of epiphytes in crown than trunk can be attributed to the following; crowns provide more micro-habitats than the trunk such as axils, forks, crevices, horizontal branches, and the cover of leaves also retains certain levels of humidity than bare upright trunks (see Figure 8). Earlier work by Gentry and Dobson [16] showed that epiphytes occurred on all trees in each stratum but were more frequent in the top storey, because epiphytes are light demanding. Trunks are generally poor in epiphytes except where trunks have several crevices on the stem or where the bole is convoluted as to allow for accumulation of litter, otherwise stems are usually impoverished in epiphytes because they lack the suitable properties for epiphyte establishment and are often shaded by the crown preventing light from reaching them [1]. Such findings are in agreement with the results of this study and emphasize the need for National Park authorities and the Forestry Department to manage primary forests in a manner that promotes increased crown cover and tree stem density.

\section{Conclusions}

It is concluded here that tree harvesting methods that target the crown would significantly alter epiphyte biomass and pattern of distribution. Such removal of tree crown would also impact on rain water retention capacity as epiphytes are known to be more efficient in intercepting rain water than ordinary foliage. Poc's [17] and Chomba and others [1] indicated that epiphytes such as mosses were estimated to intercept rainfall at $400 \%-500 \%$ of its dry weight in comparison to $60 \%-175 \%$ of the dry weight for the foliage, which makes the presence of epiphyte in any catchment forest an important component of the ecosystem contributing to the biological stability of the landscape and ecological services. 


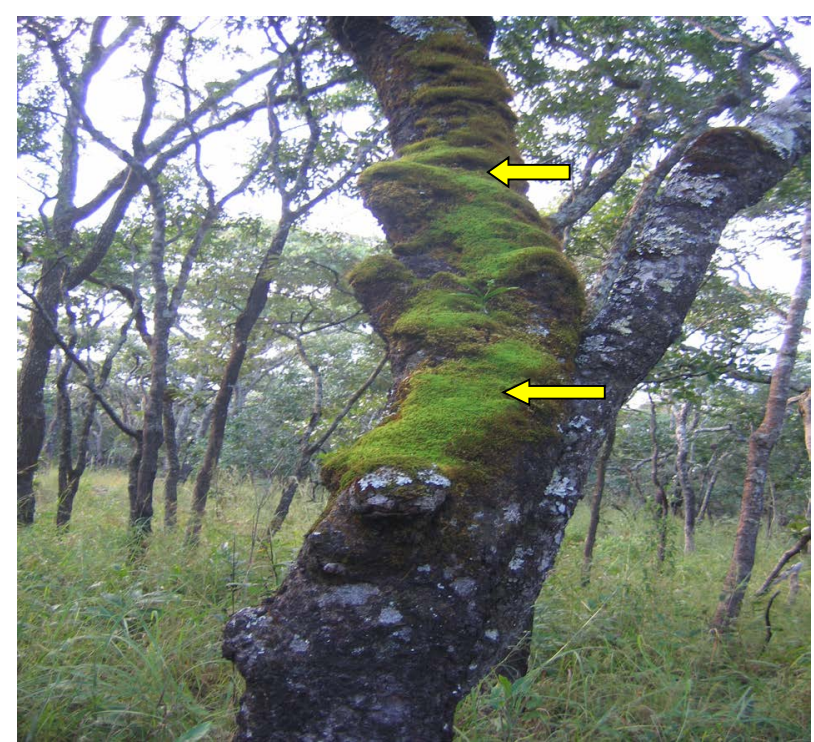

(a)

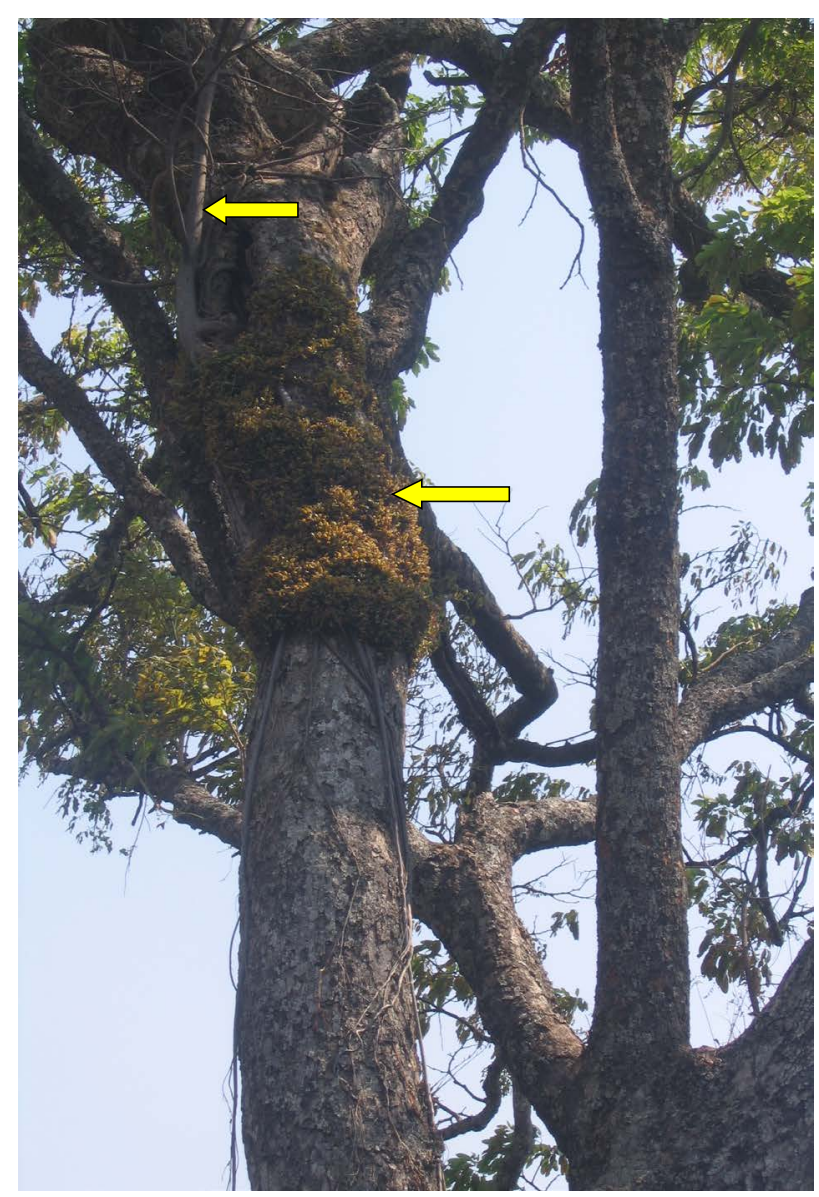

(b)

Figure 7. (a) Epiphytes on horizontal/inclined stem with suitable anchorage providing stability and accumulation of litter which retains moisture for growth; (b) Epiphytes on upright/ vertical trunks were only on rough bole textured substrates and usually where there the trunk had branches or forked. 


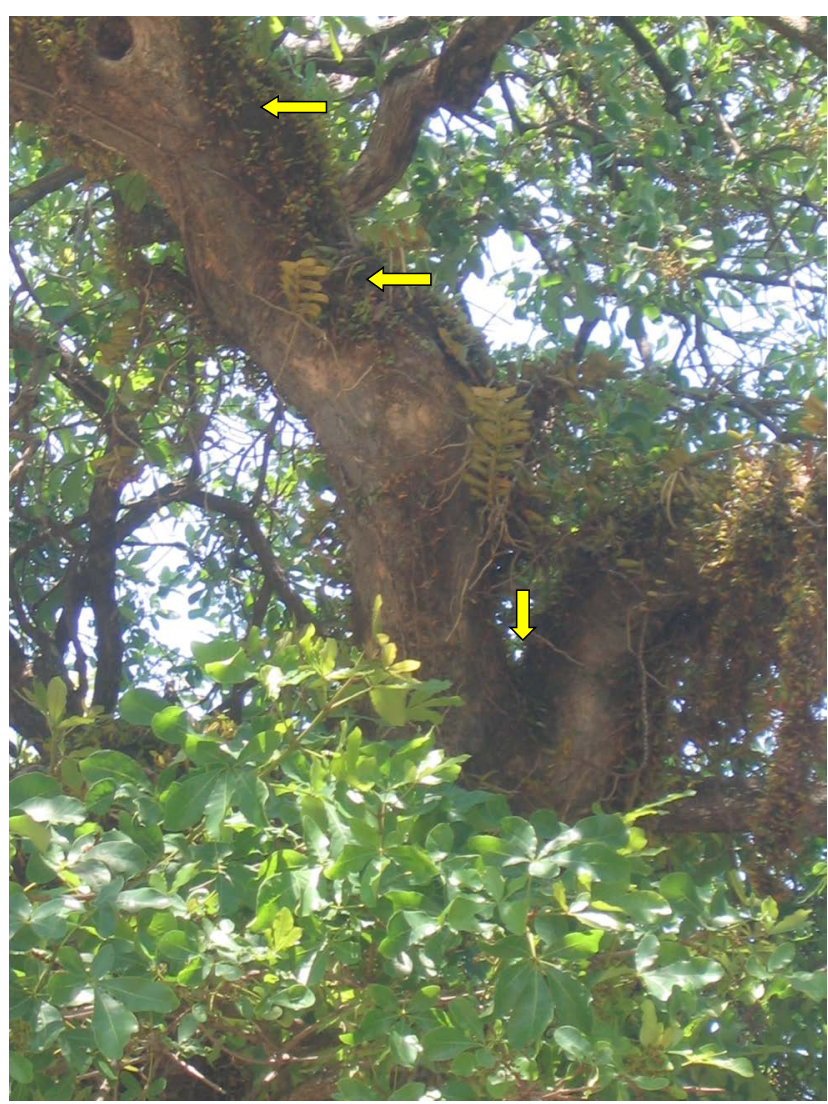

Figure 8. Host characteristics of forks, branches, invaginations, horizontal branching which are common in the crown support epiphyte establishment. Vitex doniana tree species with orchid epiphytes, Lusenga Plains National Park.

Trees should not be selectively managed on the basis of the stem structure and vertical alignments, which are usually thought to be of timber value, but for their ecological functioning. Trees that may appear to be of less timber value such as convoluted trunk, crevices in the trunk, sloping and many others should be retained for their ecological services such as water catchment.

Dead organic matter is undoubtly important to the survival of epiphytes as its water retention capacity provides a more continuous moisture supply for epiphytes than the atmosphere of bare bark. Decaying aerial organic matter is also converted into humus by fungi and micro-fauna contributing to fertility of forest soils. However, in areas with a long dry season (April to November) it can also be fuel for crown fires. Therefore, control of late fires may be absolutely necessary as these may promote crown fires which may subsequently consume aerial humus which forms a carpet on which epiphytes propagules and seedlings settle. Loss of such litter may make crowns drier as they would lose water retention capacity and become unsuitable for epiphytes. This may ultimately have a negative impact on the forests' water catchment capacity.

Local communities in the surrounding areas should be sensitized through proactive awareness campaigns to carefully avoid fires escaping their fields as they prepare them for cultivation in the late dry season when ambient temperatures are highest. If such fires ran out of control and crossed into the National Park, they would annihilate aerial epiphytic communities. The use of fire in chitemene system of agriculture which involves pollarding, lopping and at times felling the whole tree stem should be discouraged in such areas, because it transforms primary forests to secondary forests, the latter of which is not suitable for epiphytes.

In view of the high levels of deforestation in Zambia currently being one of the highest in the Southern African sub-region together with Malawi [17], ZAWA should consider extending the National Park boundary for Lusenga Plains National Park to include all the mature forests in the east of the Kalungwishi River in Mporokoso and Kaputa districts and all the riverine forests at the three waterfalls. This would secure and further enhance 
catchment functions of the area.

\section{Acknowledgements}

My colleagues particularly Professor Senzota of the Department of Zoology and Wildlife Conservation of the University of Dar es Salaam, Tanzania, provided guidance on epiphyte ecology. Park Ranger Mr. Peter Indala and all his staff worked and continue to work hard in monitoring vegetation in the National Park. They now take care not to destroy trees with epiphytes even when a new road has to be constructed they avoid cutting trees laden with epiphytes. I thank them for appreciating the role of epiphytes in water catchment functions and soil fertility in forest areas.

\section{References}

[1] Chomba, C., Senzota, R., Chabwela, H. and Nyirenda, V. (2011) The Influence of Host Tree Morphology and Stem Size on Epiphyte Biomass Distribution in Lusenga Plains National Park, Zambia. Journal of Ecology and the Natural Environment, 3, 370-380.

[2] Encyclopaedia Britannica (2010) Spanish Moss. Encyclopaedia Britannica Ultimate Reference Suite, Chicago.

[3] Kelly, D.L. (1985) Epiphytes and Climbers of Jamaican Rainforest; Vertical Distribution, Life Forms and Life Histories. Journal of Biogeography, 12, 223-241. http://dx.doi.org/10.2307/2844997

[4] Cornelissen, J.H.C. and Ter-Steege, H. (1989) Distribution and Ecology of Epiphytic Bryophytes and Lichens in Dry Evergreen Forest in Guyana. Journal of Tropical Ecology, 5, 131-150. http://dx.doi.org/10.1017/S0266467400003400

[5] Yeaton, R.I. and Gladdstone, D.E. (1982) The Patterns of Colonization of Epiphytes on Calabash Trees (Crescentia alata) in Guanacaste Province. Costa Rica. Biotropica, 14, 137-140. http://dx.doi.org/10.2307/2387743

[6] Catling, P.M., Brownwell, V.R. and Lefkovitch, L.P. (1986) Epiphytic Orchids in Belizean Grape Fruit Orchids; Distribution, Colonization and Association. Lindleyan, 1, 194-202.

[7] Catling, P.M. and Lefkovitch, L.P. (1989) Associations of Vascular Epiphytes in Guatemalan Cloud Forest. Biotropica, 21, 35-40. http://dx.doi.org/10.2307/2388439

[8] Tucker, G.F. and Powell, J.R. (1991) An Improved Canopy Access Technique. Journal of Applied Forestry, 8, $29-32$.

[9] Gentry, A.H. and Dobson, C.H. (1987) Contribution of Non-Tree Species Richness of a Tropical Rain Forest. Biotropica, 19, 149-156. http://dx.doi.org/10.2307/2388737

[10] Nadkarni, N.M. (1984) Epiphyte Biomass and Nutrient Capital of a Neotropical Elfin Forest. Biotropica, 16, $249-256$. http://dx.doi.org/10.2307/2387932

[11] Tucker, G.F. and Powell, J.R. (1991) An Improved Canopy Access Technique. Journal of Applied Forestry, 8, $29-32$.

[12] Benzing, D.H. (1981) Bark Surface and the Origin and Maintenance of Diversity among Angiosperm Epiphytes: A Hypothesis. Selbyana, 5, 248-255.

[13] Benzing, D.H. (1990) Vascular Epiphytes. Cambridge University Press, Cambridge. http://dx.doi.org/10.1017/CBO9780511525438

[14] Todzia, C. (1986) Growth Habits, Host Tree Species and Density of Hemi Epiphytes on Barro Colorado Island, Panama. Biotropica, 18, 22-27. http://dx.doi.org/10.2307/2388357

[15] Barkman, J.J. (1995) Phytosociology and Ecology of Cryptogamic Epiphytes. Van Gorcucm and Company, Assen.

[16] Gentry, A.H. and Dobson, C.H. (1987) Contribution of Non-Tree Species Richness of a Tropical Rain Forest. Biotropica, 19, 149-156. http://dx.doi.org/10.2307/2388737

[17] P'ocs, T. (1991) The Significance of Lower Plants in the Conservation of Mount Kilimanjaro. In: The Conservation of Mount Kilimanjaro, World Conservation Union, Gland. 
Scientific Research Publishing (SCIRP) is one of the largest Open Access journal publishers. It is currently publishing more than 200 open access, online, peer-reviewed journals covering a wide range of academic disciplines. SCIRP serves the worldwide academic communities and contributes to the progress and application of science with its publication.

Other selected journals from SCIRP are listed as below. Submit your manuscript to us via either submit@scirp.org or Online Submission Portal.
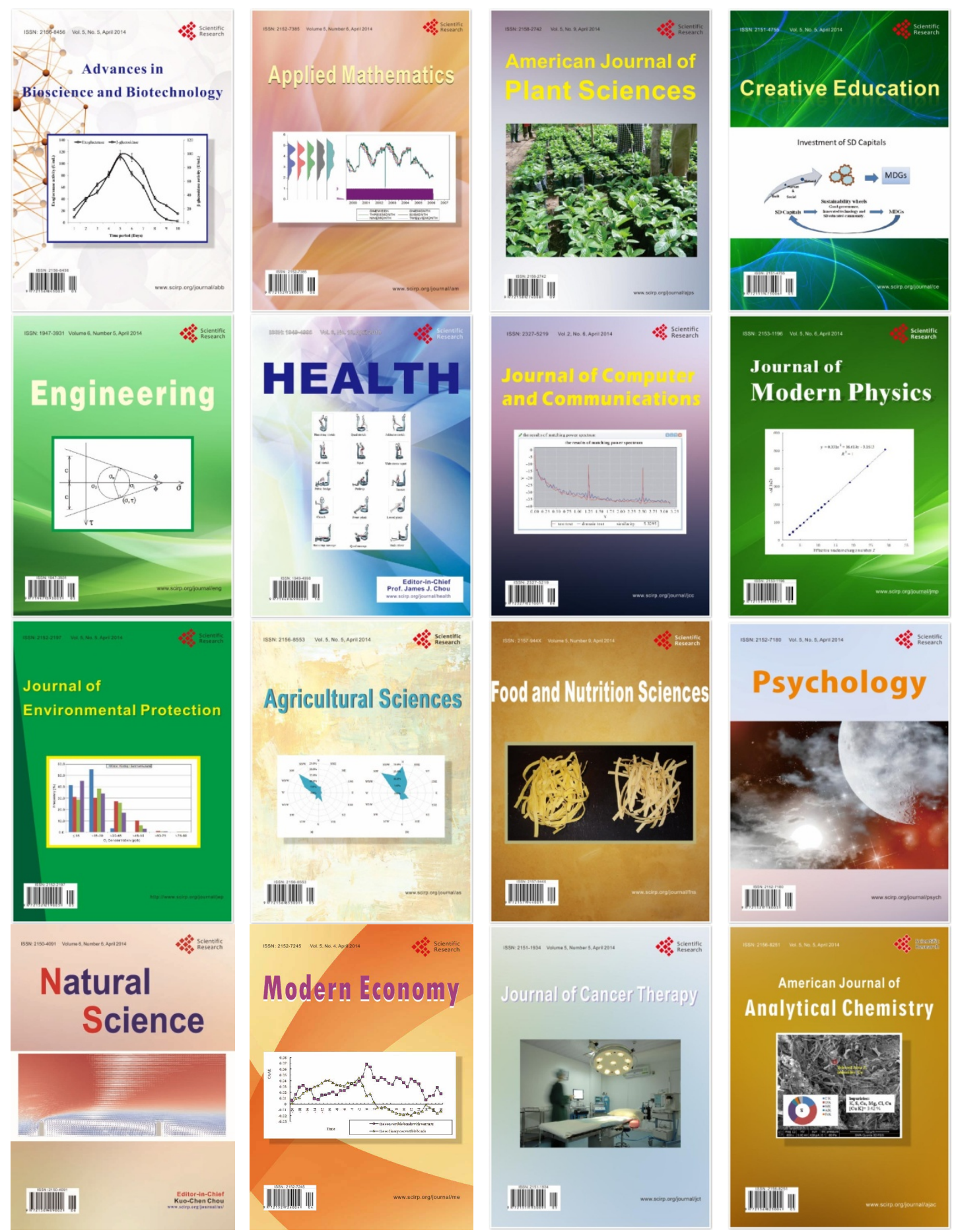